\author{
Nieder-Heitmann, Jan ${ }^{1}$ \\ Stellenbosch University
}

\title{
Christianity Among Other RELIgIONS AND SECULAR WORLD VIEWS IN THE QUEST FOR THE COMMON GOOD IN PLURALISTIC SOCIETIES
}

\begin{abstract}
Amid a plurality of religions and secular world views, some of which claim to serve the common good while others restrict themselves to the private sphere - and yet others deny Christianity and other religions's relevance in the public sphere - the church has to constantly reinterpret its own claims, as well as those of other religions and secular world views. The church has to do this in order to ascertain its relationship with other religions and world views, and their adherents in general, but more particularly with regard to specific public issues. Public theology needs to be intra-disciplinary with the theology of other religions, and in conversation with the science and philosophy of religion.
\end{abstract}

\section{INTRODUCTION}

In the West, since the Enlightenment, there exists a broad consensus that a plurality of religions in one society creates the potential for conflict and, therefore, that religions are detrimental to the common good, to unity, and to peace. Hence, religions has to be kept in check by and within a neutral state. The reason for this, it is felt, is that conflicting religious commitments cause intolerance, strife and war, and this should disqualify religions from participation in the public sphere. According to Slenczka (2010), Christians at least have more tolerance due to their awareness of their own imperfection, sinfulness, and guilt. Yet Christians, like others, should refrain from participation in public life on the basis of their religious commitments (cf. Slenczka 2010:1). Current inter-religious tensions and war in Europe tend to strengthen this conviction, and hence the constitution of the European Union grants religions only scant scope for participation in public life.

Clashes between Christians and Muslims in Nigeria and the insistence that Shari'a law be generally enforced also strengthen this view of religions. In colonial times, tribal religions that used to bolster the political claims of tribal heads were also proscribed in order to combat tribalism and its undermining of the state. This is one of the reasons why, for example Nigeria, like European countries, adopted a constitution that entrenches a secular state.

\footnotetext{
1 Dr Jan Nieder-Heitmann is a minister in the Dutch Reformed Church in South Africa and a research fellow
} of the Beyers Naudé Centre for Public Theology, Stellenbosch University. 
South Africa has a colonial history in which Christianity was initially awarded established status, unlike African traditional religions, Islam, Judaism, Hinduism, and other religions. Over time, the exclusion of the other faiths from public life became intolerable. With secularisation at much lower levels than Europe, the new South African Constitution guarantees a secular state that is religiously neutral yet affords religious organisations the right to participate in public consultation.

Therefore, one could ask whether the church - in its various institutional modalities and as an individual believer in secular vocation - should and can be involved in public life to the benefit of all on the basis of its faith commitments in plural societies? And, can the church do so in conjunction with the adherents of other religions? Furthermore, how is the church - and other religions for that matter - to respond to secular world views that deny religions participation in the public sphere?

By phrasing our topic in this manner, we simultaneously touch upon two issues that have been intricately intertwined throughout the history of Christianity, namely the relationship between Christianity and other religions with regard to public life, as well as the relationship between religions and secular world views that claim to promote the common good. ${ }^{2}$

It is not possible to consider the role of religions in the search of the common good from a Christian perspective without considering the theological interpretation and evaluation of other religions. On the other hand, considering the role of religions in the search for the common good has to deal with secular world views that deny religions any public role. To rephrase: Christian theology has to assert a role for the church in the public sphere against the exclusion that secular world views impose on it; and, to assess whether and how the church can cooperate with people that also claim a public role on the basis of non-Christian religious commitments, including those that base their claim on secular commitments.

A broad historical and theological outline of how these issues have been dealt with in the past, especially with reference to the Netherlands, South Africa and Nigeria, follows below.

\section{A SHORT HISTORY OF THE CHRISTIAN RELIGION AND THE COMMON GOOD AMID A PLURALITY OF RELIGIONS AND WORLD VIEWS}

\section{Early Christianity}

During the first three centuries of its existence, the church saw itself as a missionary community with a missionary task towards society (Goheen 2000:192). However, Christians were persecuted minorities in constant conflict with political society (Newbigin 1991:68). A salient characteristic was their self-designation as ecclesia (public assembly) as opposed to the array of other private cultic communities that existed with the blessing of the Roman Empire that understood themselves to be thiasos or heranos (private religious communities).

2 These twin issues pertain to two of the most pressing problems facing the Christian church and on which little or no consensus has been reached in a secularising and religiously pluralistic globalised world: Some decades ago already, Hans Küng (1978:25) and David Bosch (1991:476-477) had stated that the relationship between Christianity and other religions, and the relationship of Christianity with world views that promise this-worldly salvation, pose the two major unresolved issues for the world church. 
The latter were not in competition with the public Imperial cult. The church was, however, not part of the spectre of private religious societies competing with one another to present personal salvation to their members. It viewed itself

as a movement launched into the public life of the world, challenging the cultus publicus of the Empire, claiming the allegiance of all without exception (Newbigin 1980:46).

This confession was based on the good news of the incarnation that provided the clue to all of history. For claiming universal significance, the early church paid a high price in terms of persecution and suffering as it collided with the established powers, especially the Imperial cult (Newbigin 1986:100).

During the first three centuries, there were two divergent tendencies in the church regarding the theological interpretation of non-Christian religions. Both appealed to Scripture. Some supported a more positive and inclusive attitude. Justin and like-minded theologians believed that Christianity was superior to Greek philosophies and religions. The difference was, however, not absolute but rather relative. The "heathen" possessed germ cells of the truth, part of the truth. The Logos of John 1 functioned like a seed in all people and was also reflected in non-Christian religions and philosophies. Those who lived according to the principles of the Logos were by implication Christians, albeit it anonymous ones. Christianity was seen as the fulfilment of that which was partly present in heathendom. The latter served as preparation and pedagogue for the gospel in a way similar to that of the Old Testament.

Others drew a sharp distinction between Christianity and other religions and philosophies. Tertullian exposed the repulsive practices of heathendom and the foolishness of Greek philosophers in no uncertain terms. No relationship was possible between Athens and Jerusalem - between an adoration of reason and Christian faith. No one is born a Christian but becomes one through rebirth (Bosch 1976:36-38).

These early positions have kept recurring in different forms and combinations up to the present. The question regarding truth has obviously played a vital role in the relationship between Christians and non-Christians, and amongst Christians that hold divergent positions. For the purpose of this paper, the truth regarding humanity and the common good of society is the focus.

\section{Christendom}

\section{Constantine and Theodosius}

Emperor Constantine's declaration of religious freedom for all religions (313 AD) was followed by Emperor Theodosius' declaration of the Christian religion as the sole official imperial religion (380 AD), followed by the banning of all non-Christian cults in $391 \mathrm{AD}$. This brought a change in the church's views regarding its relationship to both the public sphere and to other religions.

The church's acceptance of its legal establishment, however, had its roots in the courageous insistence of the pre-Constantinian church that the incarnation was the clue to all of history and that Jesus is Lord of all. Hence, Christianity could not be a privatised cult, but 
served as proclaimer of Christ's universal rule. Did the church have much of a choice when the ancient classical world became spiritually bankrupt and turned to the church to provide it with a centre? Being faithful to its origins in Israel and the ministry of Jesus, the church simply had to assume responsibility for the political order as the culture of antiquity faded and the gods and cults of the empire failed to keep it together (Newbigin 1986:129).

\section{Augustine}

Augustine, however, still wrestled with being Christian in a pluralistic society. Inwardly and spiritually the classical world view had disintegrated, outwardly it was matched by Alaric's pillage of the Eternal City. As an old man Augustine set himself his greatest task, namely to interpret secular history in the light of the gospel. He painted a picture of the relationship between church and world that shaped thought and practice in Western Christianity for a thousand years. Not only did he provide an approach to knowledge that related science and revelation in a "synthesis" that enabled a common understanding of reality, but also related "the city of God" to "the earthly city" in a vision that was to control the relationship between church and society for another millennium in Western Europe. This vision acknowledged the coexistence at all levels of public life of pagans and Christians, the latter as "resident aliens". Even though the church was no longer persecuted and enjoyed established status, the kingdom of God had definitely not arrived in its fullness. Two commonwealths with two internal logics lived side-by-side, the one ruled by the love of self, the other by love of God. The dividing line, however, was not simply between Christians and non-Christians. The former also found themselves torn between conflicting allegiances. Christians, as resident aliens in the earthly city, were nevertheless compelled to seek the latter's good order and when called to responsibility as rulers, would have to accept it in the spirit of servants of the common good. Thus the citizens of the heavenly city would actively seek the peace and good order of the earthly city, not seeking to forestall, but patiently awaiting the final judgment when the two would be visibly separated and the heavenly city would appear in all its beauty. Meanwhile the monastic communities, such as the one to which Augustine belonged, were visible signs and preliminary realisations of a world ruled solely by the love of God in the midst of a world ruled by the love of self (Newbigin 1986:102-105).

Newbigin, similar to Bonhoeffer in his Heritage and Decay (Bonhoeffer 2005:89ff.), was particularly interested in the role played by Christian theology in shaping the understanding of reality of Christian Europe. It was much more than a new alliance between political society and Christianity, state and church. Theology took on the task of defining the relationship between the Christian understanding of reality and the failing classical world view of the Empire. It meant more than a new ethic. It entailed an alternative ontology and epistemology to the floundering ones of the Roman Empire. Not that it simply discarded Roman antiquity. The theologians of first-century Christianity provided the Empire and Europe with a new way of understanding by providing a new arche, a new starting point for the logos of the classical world, namely the Christ event, as vividly narrated in the first chapter of the Gospel of John. Ultimate reality was no longer unknowable, but revealed in the person of Jesus Christ in the 
text of the New Testament and the preaching of the church. This was captured in Augustine's famous slogan credo ut intelligam (I believe in order to know). In his Confessions he narrates how he had to give up the classical prerogative of being the subject in his failed quest for truth as he became the object of the Other who sought and found him through "the Word made flesh in the actual history of Jesus Christ". This would "henceforth be the foundation for all the great intellectual and spiritual striving which filled the remaining years of his life” (Newbigin 1995:7). Hence, “a world view which sees ultimate reality as in some sense personal” now replaced the classical world view that regarded "ultimate reality as impersonal" (Newbigin 1995:7). ${ }^{3}$ By faithfulness to the reality of Jesus Christ, we would be led by the Spirit to full knowledge of the Father - in via at present, but in its fullness at the end. This overcame the paralysing dualisms of the classical world and liberated classical thought to advance in the scientific way that it did. This "synthesis" - or rather enculturation as it may be more appropriately called currently - mainly ascribed to Augustine - sustained Europe for the next thousand years. Although it did not end the tension between the classical and the biblical ways of understanding reality, the Christian story did play the greater part in shaping Europe as a coherent political, cultural and spiritual entity (Newbigin 1995:7-14). ${ }^{4}$

Later generations of theologians, however, operated in a Europe in which the remaining vital elements of non-Christian religions had faded. Christians no longer shared common cultural and religious roots with adherents of other religions. Christians were regarded as being civilised whereas those of other faiths were considered heathen, barbarians, and a threat to the state - a position that has retained much of its appeal to many.

The rise of Islam hardened attitudes. This religion was regarded as the Antichrist that had to be conquered by the sword. Other religions, from which Europeans were cut off by Islam, were eventually viewed in a similar way. Papal permission given in 1454 to the King of Portugal to subdue Muslims, pagans, and other enemies of Christ by force, to confiscate their possessions, and to permanently turn them into slaves, set the scene for the sacking of mosques and temples by colonists and missionaries in subsequent centuries. Rome's doctrine of "no salvation outside the church" meant the eternal damnation of all others. This led to their (the adherents of other religions) temporal damnation by Christian armed forces (Bosch 1976:38-40).

However, before Muslims were expelled from Latin Christendom, their presence presented a fundamental challenge to Christendom and the millennium-old Augustinian

3 Bonhoeffer also picked up the theme of reality being ultimately personal - im-personated in Jesus Christ. This crucial understanding of reality was transposed upon antiquity to form the basis of the Christian West. Any break with this - whether represented by ancient Greek thinking or the modern revival of the preChristian European world view - was merely mythology.

$4 \quad$ Newbigin approvingly refers to Christopher Kaiser’s work on the dialogue between Christian theologians and science. The Cappadocian theologians at the end of the fourth century developed four fundamental principles based upon the creation of God and the incarnation of Christ that were to shape the development of science throughout the ages up to the present. In this way the biblical revelation redeemed and rescued classical thought from its cul de sacs and provided the basis for the subsequent development of science in Europe. It was this Christian basis that caused Europe to advance scientifically well ahead of the "far more brilliant thinking of India, China, and the Arab world ... They were part of the whole reconstitution of thought necessitated by the new fact, the action of God, the incarnation of the Word in Jesus Christ.” (Newbigin 1995:7). 
enculturation of the gospel into the culture of Roman and Greek antiquity. Muslim scholars introduced the philosophy of Aristotle. Thomas Aquinas developed a synthesis to accommodate the new epistemological challenge that it posed. ${ }^{5}$ In Aquinas' "double storey” construct he distinguished between the "lower storey" of knowledge which is accessible to all people through nature, philosophy, natural reason. Knowledge about God’s existence and the fact that God is one can be obtained here, as can the knowledge to distinguish between good and evil. This is also where the non-Christian religions fit in. The "top storey", which is the terrain of the supernatural, revelation and faith - of grace - "builds" on the lower one. It is in the top storey where Christianity is located. Non-Christian religions and philosophies therefore become the "preparation for the gospel" (Bosch 1976:41-42).

The encounter between Augustinian Christendom and Aristotelian philosophy, however, created a dualism in Western epistemology that would eventually widen to the point that all religions, including Christianity, were eventually denied participation in the public sphere.

It was only after the acceptance of the Thomistic synthesis that a change to the age old approach of the Church of Rome towards other religions appeared - at least in a certain section and also only for a limited period. The first sixteenth-century Jesuit missionaries to Asia had a much milder approach towards the religions and cultures of Japan, China, and India. This ended dramatically when the Pope recalled them all in 1773 on the insistence of other orders that vehemently opposed this approach. It was only once a similar approach had emerged in Protestant missionary circles that it again found acceptance in Roman Catholic circles (Bosch 1976:41).

Christian humanism, which is currently being revitalised among public theologians of the likes of John de Gruchy, is normally associated with the Renaissance. In a sense it revived the inculturation of Roman and Greek antiquity in Christendom. The acceptance of and respect for the common humanity of all regardless of physical and cultural differences, including religious commitments, is one of the salient traits of Christian humanism (De Gruchy 2006:30) and an important premise for life together in plural societies.

\section{The Reformation - religious pluralism and a divided Christendom}

Leading Reformers such as Luther, Calvin, Zwingli, and many of their close associates were all products of Christian humanism. Apart from producing theologians and scholars, Christian humanism also produced others who were deeply involved in public life - Erasmus of Rotterdam was one of the leading figures.

With the advent of the Reformation, for the first time in the history of the church now witnesses the development of an actual theology of religions. What the apologists, the church fathers (excluding Tertullian) and scholastic theologians offered was rather a Christian philosophy of religions (Hendrik Kraemer in Bosch 1976:42). The three leading Reformers all accepted the possibility of revelation as well as knowledge of God outside of Christianity.

5 Aquinas' construct may rightfully be called a synthesis of the gospel and philosophy as the two systems are connected in such a manner that the conflicting commitments of both are retained. A synthesis of this kind inevitably has to come apart, as eventually happened with the Thomistic construct. 
Luther knew little about Islam and interpreted it negatively. Zwingli, who essentially stayed within the tradition of humanism, was of the opinion that Greek philosophers and Roman poets will share ultimate salvation together with Old and New Testament believers. This enraged Luther to the point that he branded Zwingli a heathen. Calvin spoke in a more nuanced way of natural knowledge of God via an innate "sense for the divine" (Institutes I.3.3) or a "seed of religion” (Institutes I.3.1). Tragically, due to human corruption this does not lead to true religion but rather to people's own religious fabrications, which cannot but bear bad fruit (Institutes I.11.8). Calvin also refers to a second general source of knowledge of God, namely "general revelation”, which is disclosed in God's works. This knowledge is also suppressed (Institutes I.5.4) due to human beings' unstoppable craving for creating new religions (Institutes I.6.3) since the human spirit is a factory of idols (Institutes I.11.8) (cf. Bosch 1976:42-45).

The Reformers, especially Calvin, taught the public relevance of the gospel and basically held on to this Christian ideal. Only the Radical Reformation broke with this ideal and rather viewed the church as an alternative society within a non-Christian world. ${ }^{6}$ The Reformation, however, shattered the unity of Latin Christendom and resulted in religious wars that undermined Europe's trust in religion to supply the basic commitments towards the quest for the common good. The story of the Netherlands and the Cape of Good Hope as refreshment station of the Dutch East India Company (VOC) is part of the above history.

\section{Reformed Christendom in the Netherlands and at the Cape}

The Republic of the United Netherlands was born in the context of religious wars between Catholics and Protestants. This strife got a further ethnic colour with the Spanish monarch as protagonist on behalf of Roman Christendom. This lay the basis for the development of Dutch nationalism. The Dutch Reformed Church won established status as privileged church in the Dutch Republic. However, Catholics, other Protestants, and Jews enjoyed varying degrees of tolerance depending on the specific province and period they found themselves in. The States General convened and sponsored the National Synod of Dordrecht (1618-1619) to promote unity in its privileged church for the sake of a stable political dispensation.

This synod requested the States General to exert itself “with Christian earnestness” to promote "the procreations of the holy Gospel" in the East Indian countries where it held authority. The motivation of the Synod was that all true Christians ought to strive for the extension of God's honour among all people and desire the salvation of their neighbour. Therefore it was the States General's duty to use all means at its disposal to further this goal as the Lord had opened up countries that lacked the true and saving knowledge of God (Biesterveld \& Kuyper 1905:287-288). This is in line with Article 36 of the the Belgic Confession, which upholds civil government as agent for caring for and watching over the public domain. Its task also extends to maintaining the sacred ministry with a view to

$6 \quad$ Newbigin, Bosch, De Gruchy and others hold on to both the Reformed ecclesiology of accepting secular government and bearing public witness to the reign of God in public life, as well as an Anabaptist ecclesiology of the church being an "alternative community". 
removing and destroying all idolatry and false worship of the Antichrist; to promoting the kingdom of Jesus Christ; to furthering the preaching of the gospel everywhere; all to the end of God being honored and served by everyone as God requires in God's Word.

The VOC unilaterally initiated a chaplaincy service consisting of Dutch Reformed predicants and sick-comforters. The Company drew up its own church orders, which regulated religion in the very pluralistic contexts of East India and the Cape. The Company also employed people from various European ethnic groups, which also meant people from different nationalities and religious affiliations. Slaves and political captives from diverse ethnic backgrounds were imported or sent to the Cape. Some were Muslims. Others, like the Cape's indigenous peoples, had primal religions.

The 1624 Batavian Church Order of the VOC prohibited Chinese and other "heathen” from practising their

pagan superstition and serving the devil in public, especially in the streets, since in no Christian republic such incursions of the honour of God are to be tolerated (Church Order of Batavia, 1624, in Spoelstra 1907:572).

Non-Dutch inhabitants were thus prevented from joining such "pagan practices”. Van Riebeek's prayer on arrival at the Cape reflects this understanding of Company patronage of religion. The Classis of Amsterdam also shared this sentiment: "May the Lord of the harvest bless your [Church at the Cape] ministry among the blind heathen of the Cape so that their eyes will be opened to kiss in faith the Lord and commander of the heathen, and will walk in his ways” (Missive 180, in Spoelstra 1907:37) and that his kingdom would grow among "the heathen" and that many souls would be won for the Lord Jesus Christ (Missive 181, in Spoelstra 1907:38). Here, in quintessential Reformed fashion, we see that the winning of souls and the confession of the private and public Lordship of Christ through word and deed being kept together.

At the Cape, political society only allowed the Dutch Reformed Church to institutionalise itself. This church welcomed and cherished this privilege. It exerted its political influence to stop Lutherans from establishing a congregation or to publically propagate their faith for more than a century. Lutheran men were also not allowed to have their Reformed wives and children join the Lutheran Church as it would reportedly cause much harm to the congregations and weaken the offerings needed to help the poor. Many poor people who received diaconal assistance were neither Reformed nor Lutheran colonists, but were slaves and their children who were baptised and freed. These people would remain the liability of the diaconate of the Reformed Church once the Lutherans had formed their own congregation (Missive 220, in Spoelstra 1907:112).

Roman Catholics were also kept in check. Muslims were not allowed to practice their faith in public. The indigenous Khoina were not regarded as having any religion at all, but as being under "the reign of darkness and in the hands and bonds of Satan" - a "wretched, pitiful people” (Missive 1, in Spoelstra 1906:4) - a "nation [that] simply resists our religion” notwithstanding all efforts to convert them (Missive 10 in Spoelstra 1906:28-29). 


\section{THE ENLIGHTENMENT}

\section{The privatisation of religion}

The religious wars that followed in the wake of the Reformation caused the already existing dualism between reason and revelation to intensify. No longer was religion to be trusted with the common good. Modernity with its faith in reason and empirical experience and its alter ego, modernism, with its romantic idea of the nation, became the new leading lights in the quest for the common good. Religions, including Christianity, were relativised and viewed as expressions of an underlying common natural religion. Christianity was at most the highest evolutionary form, the crown, and fulfilment of other religions.

Nineteenth-century historical criticism relativised Christianity even further by regarding it the best religion for the West. Mission was reduced to the contribution it could make towards civilising people of other religions, whether through education, medical work, social upliftment, or the struggle for social justice. Christian missions, according to Troeltsch, had to refrain from attacking established religions and from trying to replace them (Bosch 1976:45-47).

Religion was classified under the rubric of beliefs and "values" that essentially belong to the private sphere whereas science and all its applications have to do with "facts", which properly belong to the public sphere.

The French Revolution popularised the ideas of the Enlightenment in Europe. Napoleon's conquest of the Netherlands resulted in the formation of the Batavian Republic. A sharper division between state and religion was drawn. Religions became voluntary faith-based organisations that were free to exist outside the public sphere. Under Batavian Republican rule Islam and other religions were unbanned at the Cape. Christian missions in colonies such as the Cape and Nigeria were welcome to contribute towards "civilising the heathen" and to counter the advance of Islam in the case of the latter. As the church and its missions had already been restricted from political and economic involvement in Cape-Dutch Christendom, so it also tended to be in other colonies in the nineteenth century. Missionary proclamation and practice strengthened this tendency with its other-worldly and individualised eschatology (cf. Mbiti 1971).

The new non-Western converts were the first to intensely experience religious pluralism. As minorities their experience was similar to those in pre-Christian or early Christian Europe. They had to contend with a plurality of religious claims and commitments. Christianity became the entrance to a world culture and a God who deals universally, unlike the localised and kin-bound traditional deities. Traditional African religions functioned on tribal or kinship level. Hence, Xhosa Christians tend to hold on to more than one religion by letting them function in different contexts, or to syncretise them (cf. Pauw 1975:336).

South Africa, however, witnessed a number of church initiatives aimed at serving the common good. However, the common good in a pluralistic society such as South Africa is often readily compromised by sectarian, group interests. So, for example, the DRC followed the views of its Afrikaner membership in the rebellion against British rule. This eventually 
resulted in the support of this church for apartheid and a regime that decided on behalf of other ethnic groups what was deemed to be good for them. Many church bodies took the side of those suffering under apartheid - both inside South Africa and ecumenically. The then Dutch Reformed Mission Church's declaration of a status confessionis and subsequent Belhar Confession ushered in a new era in the role of the church with regard to the common good. Hitherto the church had not spelt out the public relevance of gospel and church so forcefully in confessional terms.

Decolonisation brought a new dimension of inter-religious encounter. The post-colonial African states adopted new policies regarding religion. As mentioned earlier, under the new South African Constitution, for instance, the state is no longer Christian but a liberal democracy that is neutral with regard to religion. Religious communities and organisations of various persuasions can, however, participate in public processes. Nigeria's federal constitution is similar. However, some northern Nigerian states have obtained the right to function under Shari'a law.

The influx of non-Western Christians and adherents of other religions into Europe from former colonies and other countries has influenced Europeans' religious and cultural views. Non-Christian religions, which seemed to be in decline a century ago, have been reasserting themselves - also in Europe.

Despite a long history of secularisation, religion is currently very much alive in Europe. The war that ravaged the old Yugoslavia served as an indication that the old religions of Europe - Roman Catholicism, Orthodoxy and Islam - are forces to be reckoned with. Europe's imperial past, the collaboration of Western missions with colonial forces, and Europe's history of anti-Semitism and crusades contribute to a guilty conscience and reluctance if not an aversion on the side of Europe's dwindling numbers of Christians to bear witness to the gospel or to regard the gospel as the sole truth for all. European paganism is being revived. Katzenstein (2006:7-8), quoting Peter Berger, describes the European way with religion as a strong survival of religion, most of it generally Christian in nature, despite the widespread alienation from organized Churches. A shift in the institutional location of religion, then, rather than secularization, would be a more accurate description of the European situation.

Newbigin points out how relativism has resulted in widespread religious pluralism in Brittain. This ideology entails

the belief that the differences between the religions are not a matter of truth and falsehood, but of different perceptions of the one truth; that to speak of religious beliefs as true or false is inadmissible. Religious belief is a private matter. Each of us is entitled to have - as we say - a faith of our own (Newbigin 1989:14).

Judged by a survey done for the European Union in 2005, pluralism also seems to be common in the Netherlands. One can assume that the 37\% that believe there is some sort of spirit or life force (compared to a European average of 27\%) are adherents of different religions. This "new religion or spirituality" is more noticeable in certain Protestant countries, such as Sweden or Denmark, as well as in the Czech Republic and Estonia. Among Dutch respondents, 
$34 \%$ believe that there at least is a god (52\% EU average). The remaining $27 \%$ believe there is not any sort of spirit, god of life force (EU average 8\%) (Social Values, Science and Technology 2005:9, 11).

In Africa the name of Nigerian theologian and Methodist churchman, E. Bolaji Idowu looms large in this respect. In his Olodumare: God in Yoruba belief (1962), he reflects upon the relationship between Christianity and his ancestral African traditional religion in relativist terms.

Since 1910 the theology of religions has been an important theme at numerous world mission conferences. The latter can be typified as follows: Edinburgh (1910): Christianity as “fulfilment”; Jerusalem (1928): a common front of religions against secularism; Tambaran (1938): emphasis on the discontinuity between religions and divine revelation. Since 1955 there has been a growing tendency to return to the position of the apologist Justin and to emphasise the idea of "fulfilment" (Bosch 1976:29-30). John Mbiti is the quintessential advocate of this position among African theologians (Cf. Nieder-Heitmann 1981). It has become customary to classify this view regarding the relationship between Christianity and other religions as "inclusivist".

In reaction to this development, some Evangelical Christians have assumed an exclusivist position, which argues for complete discontinuity between Christianity and other religions. Important for our discussion is that behind their assessment of other religions lies the belief that Jesus Christ is in reality only the head of the church and not also of the cosmos, whereas the reigning ecumenical theology can partly be ascribed to the Reformed doctrine of the universal reign of Christ (Bosch 1976:211). Evengelicals largely give up on the present world as being under the spell of evil and all hope is placed on the consummation with the return of Christ. The search for the common good here and now is seen more or less as support services for proclaiming the gospel of ultimate, future or heavenly salvation. Of a quest for the common good in conjunction with the adherents of non-Christian religions or secularised people there is little or no evidence.

The exclusivist position is currently associated with the rise of fundamentalism - not only on the side of Christians, but also on that of other religions. Positivism and scientism essentially assume the same fundamentalist and exclusivist position towards religions and their public claims.

A fourth interpretation of the problem regarding the relationship between Christianity and other religions, with which I concur, is the paradox that there is both continuity and discontinuity between Christianity and other religions. This interpretation took form at the 1928 Jerusalem missions conference as a result of Karl Heim's contribution. Emil Brunner held on to the paradox of religions being the products of both God's primordial revelation and original sin. Hence, Jesus is both the fulfilment of and judgement on all religion. Hendrik Kraemer, especially in his later phase, reached a similar conclusion along a different train of thought. These and other theologians claimed that they represent the best of the tradition of the Reformation as well as biblical theology. First, they held on to the exclusivist claim of the unique truth of the revelation in Christ and the sufficiency of Christ alone for salvation, which rules out non-Christian religions as vehicles of salvation. Second, they maintained the 
inclusivist claim of the universality of God's grace that keeps the possibility of the salvation of non-Christians open and acknowledges God's gracious activity in the lives of all human beings. The latter is reflected in our common religious awareness and quest for God - which, due to human sinfulness, however becomes misdirected towards idolatry. Beyerhaus insisted on a third pole in a biblical theology of religions, namely an acknowledgement of the sphere of influence of demonic powers (Bosch 1976:128-129, 170-174).

This interpretation rejected the relativist, pluralist position by maintaining that each religion is unique, indivisible, and incomparable. Therefore no synthesis can be successful. Each religion revolves around its own axle (Bosch 1976:174-184). Religion entails commitments pertaining to the ultimate question of truth and these commitments are mutually irreconcilable (Slenczka 2010).

This does not exclude the experience of many a missionary and new Christian convert of having been challenged and enriched by other religions causing them to reinterpret their Christian faith. You have not understood other religions

until you have been compelled to interpret your own Gospel in entirely new terms. You have not really understood another religion unless you have been tempted by the insights of this other religion (Walter Freytag in Bosch 1976:219).

\section{TOWARDS A PUBLIC THEOLOGY OF RELIGIONS AND IDEOLOGICAL PLURALITY}

The task of public theology is to ascertain what the public relevance of the gospel is. Is it simply a matter of ethics, or is it inherently part of the essential faith commitments of the church? In pluralist societies, public theology needs theology of religions to discern the public role of the church. Theology of religions has unfortunately been focussing on the issue of salvation. This is not necessarily wrong, as salvation in Christian terms indeed is a crucial issue. However, in concurrence with Newbigin, Bonhoeffer, Moltmann, and De Gruchy, salvation should be viewed as entailing more than ultimate salvation associated with the consummation but should also be understood in penultimate terms, having to do with humanising people, the socialising of humanity, restoring justice and peace for all of creation, etc. (Newbigin 1989:176; Moltmann 1967:329; cf. De Gruchy 2002). The Reformed concept of universal grace is also useful in this respect (cf. Bavinck 1895:238-240). Collaboration with or, when called for, resistance to people of other religious and secular commitments has to do with bearing witness to both the penultimate and the ultimate salvation in Jesus Christ.

Newbigin (similar to De Gruchy) bases public cooperation between Christians and non-Christian believers on the Christian premise that all people share in the human story. Although Christians know the meaning and end of the story according to the gospel, the grace of God also works in others with whom we share the human story. These others may be Christians, Muslims, Hindus, secular humanists, Marxists, or of some other persuasion. We have to continually decide what our role in this story is. These decisions we cannot take without others of different persuasions (Newbigin 1989:181). This does not mean that Christians compromise the truth of the gospel with regard to the human story. Cooperation is the locus for dialogue and for Christians to give account of the faith that inspire them 
towards serving the common good. This faith is to be offered in bold humility as the common story that holds the promise of the penultimate and ultimate salvation of the world. Christian humanism affirms the essential importance of our common humanity on the basis of the incarnation. Our being Christian means that we have claimed the restoration of our humanity in Christ. To participate in the restoration of human dignity means to be proclaiming God's salvation of humanity.

Theologians have also dealt with the claim of the modern scientific world view, which denies all religious commitments the status of public truth and hence deny people participation in the public sphere on the basis of their religious commitments. The story of the hegemony of this world view in Europe is well known. It has also made deep inroads into South Africa and further afield in the African continent (cf. Nieder-Heitmann 2002, 2003).

A wider rationality that overcomes the Enlightenment's radical distinction between facts and values and that leaves room for a fiduciary framework is needed. Commitment, tacit or personal knowledge, is important not only in the case of one's religious paradigm, but also for a particular scientific world view or ideology (Bosch 1991:352-355, 358-361; also see the summary of Newbigin's position in Goheen, 2000:376-389). Hence, the Christian interpretation of world views bear resemblance to the Christian interpretation of other religions.

The church is entitled to participate in the public sphere and should claim this right while it simultaneously defends the same right for people of other commitments. The days are past when Christianity could coerce others into agreement with Christian commitments and the policies into which these commitments are translated.

It is important that the church should be mindful that their's is also a religion, which bears all the imprints of human sinfulness as Barth and Kraemer have rightfully pointed out. We are also subject to culturally determined world views and ideologies and these varying and often conflicting commitments reside together in a variety of ways. The story of the Dutch Reformed Church (in South Africa) and apartheid is telling of the folly of synthesising the gospel and ideology - in this case nationalism.

Pluralism which disregards the importance of religious and scientific commitment, which marks the post-modern condition, results in "anarchic pluralism" and does not bode well for the common good of society. Instead of this, Newbigin propagates what he calls “committed pluralism” where Christians participate in public debates and action on the basis of their commitment to the gospel together with the adherents of other religions and supporters of other ideologies. Christians have to convince their interlocutors that positions they take regarding specific public issues serve the common good better than the positions that others take. However, they should also be open to all signs of God's grace at work in the life and work of people that do not know Jesus as the Christ - whether they live by commitments that are either religious or secular in nature (cf. Newbigin 1989:180). This does not mean that non-Christians or secularised people will accept Christian premises. But, as Stephen Neill advises, we should rather seek "common areas of concern rather than greater or less agreement in concepts and ideas” (in Bosch 1976:184). 
Christians are needed who achieve the highest standards of excellence in all fields of public life by being shaped by the story of the Bible - a large number of people who form groups in which to reflect on the implications of the gospel for their respective public spheres and to set the tone in them. For this the church as a whole needs to recover its nerve and risk proclaiming the truth from a perspective of faith, despite the disapproval of modernity or the possibility of the "developing world" accusing Christians of cultural imperialism (Newbigin 1991; 1994:74, 157, 167-168, 173-176, 183; 1953:5-6). This reminds one of how Bonhoeffer viewed the freedom of the church, namely as faithfulness to the gospel, notwithstanding the price in suffering that sometimes has to be paid. Not simply freedom from state interference as Liberal Anglo-Saxon Christians that supported the church struggle, but rather as active participation in the business of this world (cf. Nieder-Heitmann 2007:40). Christians should

be eager to cooperate with people of all faiths and ideologies in all projects which are in line with the Christian's understanding of God's purpose in history (Newbigin 1989:181).

\section{CONCLUSION}

Christian public witness in a context of a plurality of religions and world views compels the church to reflect upon the relationship between the all-encompassing gospel it professes and other religions and secular world views that also claim to serve the public interest. This calls for a Christian theological interpretation of particular religions and world views in a manner that dialectically holds on to both the contradictory forces of divine intervention, as well as the part played by demonic powers. This corresponds with the tension between the human story as one of being created in the image of God, of being endowed with a sense of the divine on the one hand, yet also being totally depraved on the other hand. This kind of interpretation takes place as Christians assume their place in the public sphere on the basis of their faith commitment alongside people who do not share this commitment but have their own. Where different commitments allow for cooperation with regard to particular public issues, Christians should participate in accordance with their commitment to the gospel and in so doing bear witness to the gospel through word and deed. Conversely, where different commitments result in divergent views of the common good and how to pursue it, Christians should voice and advance their views in ways that are ethically justifiable in plural societies.

\section{BibLIOGRAPHY}

Bavinck, H. 1895. Gereformeerde Dogmatiek. Volume 1. Kampen: J.H. Bos.

Biesterveld, P. \& Kuyper H.H. 1905. Kerklijk handboekje bevattende de bepalingen der Nederlandsche Synoden en andere stukken van beteekenis voor de regeering der kerken. Kampen: J.H. Bos.
Bonhoeffer, D. 2005. Ethics (Dietrich Bonhoeffer Works. Volume 6). Minneapolis, MN: Augsburg.

Bosch, D.J. 1976. Teologie van die godsdienste: Sending- en Godsdienswetenskap MSR 303 Gids 1. Pretoria: Universiteit van Suid-Afrika.

- 1991. Transforming mission: Paradigm shifts in the theology of mission. Maryknoll, NY: Orbis. 
De Gruchy, J.W. 2006. Being Human: Confessions of a Christian Humanist. London: SCM.

— 2002. Reconciliation: Restoring Justice. Minneapolis, MN: Fortress.

NGK Algemene Sinode (DRC General Synod). 2007. Agenda. Deel III. Aanvullende Verslae en Handelinge van die 13de vergadering van die Algemene Sinode van die Nederduitse Gereformeerde Kerk. [Retrieved 15 January 2010] http://www.ngkerk.org.za/documents/ Agenda2007Deel3.pdf

Goheen, M.W. 2000. "As the Father has sent Me, I am sending you”: J.E. Lesslie Newbigin's Missionary Ecclesiology. Zoetermeer: Boekencentrum.

Idowu, E.B. 1962. Olodumare: God in Yoruba belief. London: Longman.

Katzenstein, P.J. 2006. Multiple modernities as limits to secular Europeanization? In: T.A. Byrnes \& P.J. Katzenstein (eds). Religion in an expanding Europe. Cambridge: Cambridge University, $1-33$.

Küng, H. 1978. On being a Christian. Glasgow: William Collins Sons.

Mbiti, J.S. 1971. New Testament eschatology in an African background. London: Oxford University.

Moltmann, J. 1967 Theology of Hope. London: SCM.

Newbigin, J.E.L. 1953. The Household of God. New York, NY: Friendship.

- 1980. Your Kingdom Come: Reflections on the theme of the Melbourne Conference on World Mission and Evangelism, 1980. Leeds: John Paul the Preacher's.

- 1986. Foolishness to the Greeks: The Gospel and Western Culture. Grand Rapids, MI: Eerdmans.

- 1989. The Gospel in a pluralist society. Grand Rapids, MI: Eerdmans.

— 1991. Truth to Tell: The gospel as public truth. Grand Rapids, MI: Eerdmans.

- 1994. A Word in Season: Perspectives on Christian world missions. Grand Rapids, MI: Eerdmans.

- 1995. Proper confidence: Faith, doubt and certainty in Christian discipleship. Grand Rapids, MI: Eerdmans.
Nieder-Heitmann, J.H. 1981. An Analysis and evaluation of John S. Mbiti's theological evaluation of African Traditional Religions. Unpublished MTh Dissertation. Stellenbosch University.

— 2002. The Gospel and Our Culture Network in North America (GOCN): Translating the challenge into a particular cultural context. Missionalia 30(3):443-472.

— 2003. The Missionary Challenge of Christendom and Modernity in South Africa: A Dutch Reformed Account. International Review of Mission XCII(365):178-191.

— 2007. Christendom at the Cape: A critical examination of the early formation of the Dutch Reformed Church. Unpublished PhD Dissertation. University of Cape Town.

Pauw, B. 1975. Christianity and Xhosa tradition: Belief and ritual among Xhosa-speaking Christians. London: Oxford University.

Slenczka, N. 2010. Religious commitment and the plurality of religions. Unpublished lecture at the Faculty of Theology, Stellenbosch University, South Africa, 21 September 2010. (Available from author.)

Social Values, Science and Technology. In: Special Eurobarometer 225/Wave 63.1 - TNS Opinion \& Social, June, 2005. [Retrieved 17 January 2010] http://ec.europa.eu/public_opinion/ archives/ebs/ebs_225_report_en.pdf

Spoelstra, C. 1906. Brieven van die Kaapsche kerken aan die Classis Amsterdam 1655-1804. Bouwstoffen Voor de Geschiedenis der Nederduitsch-Gereformeerde Kerken in Zuid-Afrika, Volume I. Amsterdam/ Kaapstad: Hollandsch Afrikaansche Uitgevers Maatschappij.

- 1907. Brieven van de Classis Amsterdam e.a. aan de Kaapsche kerken enz. 1651-1804. Bouwstoffen Voor de Geschiedenis der Nederduitsch-Gereformeerde Kerken in Zuid-Afrika, Volume II. Amsterdam/ Kaapstad: Hollandsch Afrikaansche Uitgevers Maatschappij.

\section{KeyWords / TREFWOORDE}

Common good / Algemene belang

Pluralist societies / Pluralistiese samelewings

Theology of religions / Teologie van godsdienste

Public theology / Publieke teologie

Secular world views / Sekulêre wêreldbeelde 
Nieder-Heitmann, Jan

Dr Jan Nieder-Heitmann

15 Bates Drive

Bellville

7530

SOUTH AFRICA

E-mail: niederheitmann@telkomsa.net 